Univerzitet u Beogradu
Poljoprivredni fakultet
Institut za poljoprivrednu tehniku
Naučni časopis
POLJOPRIVREDNA TEHNIKA
Godina XLVI
Broj 1, 2021.
Strane: $31-46$
Faculty of Agriculture
Anstitute of Agricultural Engineering
Scientific Journal
Year XLVI $1,2021$.
Pp: $31-46$

UDK: $665.3 ; 631.30$

Original Scientific paper

Originalni naučni rad

DOI:10.5937/PoljTeh2101032O

\title{
POSTHARVEST PROCESSING, PACKAGING AND STORAGE OF AFRICAN OIL BEAN SEED
}

\author{
Augustine Onyekachi Igbozulike ${ }^{* 1}$, Victor Ifeanyichukwu Obiora Ndirika ${ }^{1}$, \\ Kayode Joshua Simonyan ${ }^{1}$ \\ ${ }^{I}$ Agricultural and Bioresources Engineering Department, College of Engineering \\ and Engineering Technology, Michael Okpara University of Agriculture, Umudike
}

\begin{abstract}
The underutilization of African oil bean seed necessitated the study of its post-harvest operations. This work reviews the status of research on postharvest processes of African Oil Bean (AOB) seed. Information was sought through a search query with African oil bean post-harvest processing, packaging and storage as keywords on Google Scholar, internet, publishers' website, textbooks and oral interview with local processors. The results showed that researchers have focused on the fermentation, proximate, phytochemical, mineral and vitamins composition of AOB seeds. This study also revealed the dearth of research on characterization, improved variety, packaging, storage, value addition and oil extraction from AOB seeds. Research on postharvest handling, storage, packaging and processing of AOB seed is imperative for optimal utilization of the seed, and to prevent the prevalent post-harvest losses.
\end{abstract}

Key words: African oil bean seed, packaging, processing, storage, value addition

\section{INTRODUCTION}

The African oil bean (Pentaclethra macrophylla Benth.) is a tropical tree crop treasured for the multipurpose usefulness of its seed, pod, timber, bark, root and leaf.

\footnotetext{
${ }^{*}$ Corresponding Author. Email address: austin.igbozulike@gmail.com
} 
The crop is native to Africa, with the distribution cutting across the Cameroon, Cote d'Ivoire, Democratic Republic of Congo, Ghana, Niger, Nigeria and Togo rain forest zones [1].

The AOB is known in Nigeria as ugba or ukpaka, apara and ukana among the Igbo, Yoruba and Efik tribes, respectively. The crop belongs to the family of Leguminosae (Mimosoideae) with no recognized varietal characterization [1-3].

The crop flowers and produce green dicotyledon pods that changes to brown on maturity. Each pod contains up to 10 seeds that are glossy brown, and at maturity, the pod splits open explosively scattering its seeds up to a distance of $20 \mathrm{~m}$ from the tree [2]. After the explosion, the pods usually curl up. The seeds of African oil bean are flat in shape, hard, but smooth in texture and have an average length of $56.18 \mathrm{~mm}$ and width of $37.89 \mathrm{~mm}$ [4-5]. The seed is a good source of minerals, vitamins (Table 2), protein, carbohydrate, crude fibre, oil (Table 3), and contain many phytochemicals (Table 4). These researchers [6] found that AOB seeds protein content is greater than those of high animal protein sources like beef, oyster, pork and fishes.

Table 1. Importance of various parts of African oil bean tree (Adapted from [1])

\begin{tabular}{|c|c|c|}
\hline Tree part & Uses & Description \\
\hline Fruit pod & Fuel & $\begin{array}{l}\text { Empty dry pods are used as } \\
\text { firewood for cooking, and } \\
\text { charcoal production }\end{array}$ \\
\hline Timber & Wood work & $\begin{array}{l}\text { The wood is used in carving } \\
\text { household utensils in Ghana } \\
\text { and Nigeria }\end{array}$ \\
\hline Pod ash & Tannin or dyestuff & $\begin{array}{l}\text { Ashes of burnt pods are used } \\
\text { made into mordant dyes }\end{array}$ \\
\hline \multirow[t]{3}{*}{ Seed } & Food & $\begin{array}{l}\text { Seeds are processed into ugba } \\
\text { which is eaten as a snack or } \\
\text { used as a condiment for soup, } \\
\text { salad and many local sauces }\end{array}$ \\
\hline & Lipids & $\begin{array}{l}\text { The seed is good source of } \\
\text { seed oil }\end{array}$ \\
\hline & Decoration & $\begin{array}{l}\text { Seeds are used for making } \\
\text { beads, necklaces and rosaries }\end{array}$ \\
\hline Stem & Medicine & For treating diarrhea \\
\hline Leaves & Soil improver & $\begin{array}{l}\text { Improves soil fertility; for } \\
\text { herbal medicine in treating } \\
\text { wound and diarrhea. }\end{array}$ \\
\hline Tree & Ornamental & $\begin{array}{l}\text { The tree is planted as } \\
\text { ornamentalplant }\end{array}$ \\
\hline
\end{tabular}

In other to maximize the protein constituent, a texturized vegetable protein from AOB seed that will serve as a meat analogue at optimal parameters of $92.45^{\circ} \mathrm{C}$ barrel temperature, $101.48 \mathrm{rpm}$ screw speed, $59.63 \%$ feed moisture, and 1\% AOB seed protein concentrations was developed [7]. 
A work by [8] posits that the seed is a good source of lipase. AOB seed improves metabolism and possess anti-atherogenic property [9]. Some researchers [10] recommended the use of the seed in the treatment of diabetes because of the hypolipidemic activities it exhibited.

According to [11], AOB seed could help to improve kidney functionality. The seed, also, contains anti-inflammatory and analgesic properties and is used to treat gonorrhoea and convulsions in Cameroon [12]. Besides, it is an excellent raw material for the manufacturing of cosmetics, oil paints, varnishes, edible oil for cooking, and margarine production [13]. The oil of AOB seed is relatively high in viscosity compared to other under-exploited seeds in Africa like Baobab, African pear, African nutmeg and fluted pumpkin seed [14]. Investigation by [15] suggests that the oil of AOB seed is a good raw material for pharmaceutical industries because the extract from the seeds can inhibit the growth of micro-organisms such as B. cereus, B. lichemiformis, L. species, E. coli and $C$. albican.

The stem, bark, root, hull and pod of AOB are equally important to man (Table 1).

Table 2. The nutritional contents of African oil bean seed

\begin{tabular}{lccccc}
\hline Minerals & \multicolumn{5}{c}{ Compositions } \\
\hline Calcium & $($ ppm $)$ & $\left(m g 100 g^{-1}\right)$ & $\left(\mathrm{mg}^{-100 g^{-1}}\right)$ & $\left(\mu g^{-1}\right)$ & $\left({\left.\mathrm{mg} 100 g^{-1}\right)}^{-1}\right.$ \\
Copper & 104.5 & 1.10 & - & 8.16 & 2.89 \\
Iron & - & 0.98 & - & 0.05 & - \\
Lead & 34.8 & 4.23 & - & 1.60 & 0.13 \\
Magnesium & - & - & - & 3.94 & - \\
Manganese & - & 0.30 & - & 4.86 & 11.10 \\
Phosphorous & - & - & - & 0.72 & - \\
Potassium & 101.6 & 1.51 & - & 0.06 & - \\
Sodium & 181.3 & 0.65 & - & - & 4.95 \\
Zinc & 236.2 & 0.18 & - & - & 5.28 \\
\hline Vitamins & - & 1.31 & - & - & 3.31 \\
\hline Ascorbic acid & - & 10.56 & - & - & - \\
Niacin & - & 2.10 & 2.00 & - & - \\
Riboflavin & - & 0.18 & 0.11 & - & - \\
Thiamine & - & 0.25 & 1.10 & - & - \\
\hline References & {$[13]$} & {$[16]$} & {$[17]$} & {$[18]$} & {$[19]$} \\
\hline
\end{tabular}

In their work, [19] found that AOB seed contains high levels of some antinutritional and toxic factors which are eliminated during cooking and fermentation. The fermented AOB seed sliced or shreds are commonly known as ugba. The ugba is prevalent in Eastern Nigeria, and is usually consumed as a snack or a condiment for preparing African salad, soup, porridge yam, cocoyam, meat (nkwobi), among others delicacies.

Fermentation improves the amino acids and nutritional contents of ugba [20, 21]. Also, fermentation increases the proximate composition and reduces the phytochemical content of the seed [16, 19, 22]. The kinetics of AOB fermentation is influenced by boiling time and slice thickness [23]. 
The bacteria responsible for fermenting of AOB, according to [24], are Bacillus pumilus and Bacillus sphaericus, apart from Bacillus licheniformis and Bacillus subtilis.

In their study, [25] discovered that the starter culture fermented ugba is rated higher by the consumers in terms of consistency, aroma and taste than those obtained from the markets. It has been found that African oil bean seeds fermented with oil palm inflorescence ash have better chemical and microbial composition than the one processed without the oil palm ash [26]. The fermentation of AOB seed enhances its oil extraction [27]. Though fermentation is necessary for processing AOB seed into ugba, [28] found a high prevalence and co-contamination of different potentially toxigenic fungi on $u g b a$ and other fermented foods in Nigeria. Extract from the seed, as suggested by [29] could be used for bio-preservation of condiments against pathogens that spoil food.

Table 3. Proximate composition of raw, boiled and fermented African oil bean seeds (Adapted from, [16])

\begin{tabular}{lccc}
\hline Constituents & Raw & \multicolumn{1}{c}{ Boiled } & Fermented \\
\hline Crude Protein $(N \times 6.25)$ & $24.06 \pm 0.22^{b}$ & $25.59 \pm 0.11^{b}$ & $28.25 \pm 0.20^{a}$ \\
Crude fiber & $2.80 \pm 0.11^{b}$ & $2.66 \pm 0.10^{b}$ & $3.76 \pm 0.22^{a}$ \\
Lipids & $52.50 \pm 0.20^{b}$ & $51.40 \pm 0.30^{b}$ & $44.20 \pm 0.10^{a}$ \\
Ash & $2.70 \pm 0.20^{b}$ & $3.04 \pm 0.22^{b}$ & $1.86 \pm 0.30^{a}$ \\
Carbohydrates & $17.94 \pm 0.10^{b}$ & $17.31 \pm 0.11^{b}$ & $21.93 \pm 0.22^{a}$ \\
Calorific value $\left(\mathrm{Cal} \mathrm{g}^{-1}\right)$ & $640.50^{b}$ & $634.20^{b}$ & $598.52^{a}$ \\
\hline
\end{tabular}

Values with superscript that are the same not significantly different at $p<0.05$.

Though not listed among the 101 orphaned crops in Africa [30], the African oil bean can be regarded as an orphaned crop because of inadequate research on the crop. This implies that African plant breeders, sociologists, anthropologists, nutritionists, policymakers, scientists, farmers, government representatives, universities and various other stakeholders that compiled the list did not consider the crop for inclusion in the neglected African crops. This reality poses a serious danger for the survival of the crop in a few decades, if nothing is done to boost research on the crop.

Table 4. Phytochemical compositions of African oil bean seed

\begin{tabular}{lcc}
\hline Components $\left(\mathrm{mg} 100 \mathrm{~g}^{-1}\right)$ & {$[16]$} & {$[31]$} \\
\hline Alkaloid & $1.88-8.96$ & $11.24+0.01$ \\
Flavonoid & $0.28-0.90$ & - \\
Oxalate & - & $1.39+0.01$ \\
Phenol & $0.02-0.75$ & - \\
Phylate & - & $1.17+0.01$ \\
Saponin & $0.22-4.96$ & $3.20+0.01$ \\
Tannin & $3.0 x 10^{-3}-0.49$ & $0.95+0.01$ \\
\hline
\end{tabular}

Hence, this study is aimed at reviewing the importance of African oil bean seed, the status of postharvest research on the seeds' processing, handling, storage, value addition, and to highlight the research needs of the crop. 


\section{PRODUCTION AND PROPERTIES}

\section{Production of African oil bean seed}

The African oil bean trees grow in the wild until recently when the domestication has started. However, the wild still makes up a higher percentage of total production. Currently, there is neither any empirical data on the quantity produced annually nor any known commercial plantation. It was showed by [12] that the seeds and stem cuttings are used in propagating the crop. The seeds are dispersed naturally (during the splitting of the pods) or manually after harvest. It can also be propagated by air-layering or budding. The budded trees start fruiting after 3 years whereas the stem-cuttings may produce seeds after four years [32].

\section{Engineering properties of African oil bean seeds}

Engineering properties of biomaterials are essential in designing their postharvest processing machines, storage facilities and handling equipment [33, 34]. The average major, intermediate and minor diameters of African oil bean seed at $14.5 \%$, moisture content were $65.332 \mathrm{~mm}, 60.269 \mathrm{~mm}$ and $59.584 \mathrm{~mm}$, respectively [35]. At the moisture content of $8.73 \%$ dry basis, [5] obtained values for these properties the major, intermediate and minor diameters of the seeds averaged $56.18 \mathrm{~mm}, 37.89 \mathrm{~mm}, 12.01 \mathrm{~m}$ with standard deviations 8.46, 3.82 and $1.66 \mathrm{~mm}$ respectively. They, also, got the equivalent diameter, sphericity and porosity as $32.51 \mathrm{~mm}, 0.523 \mathrm{~mm}$ and $51.56 \mathrm{~mm}$, respectively. The seed dimensions are relatively larger than many oil seeds. The gravimetric properties show that the seed is heavier than water [5, 35]. In addition, [36] found the angle of repose and friction coefficient to be $17.20^{\circ}$ and 0.31 , respectively. In their own work, [3] investigated the mechanical properties of the seed at moisture content range of 15.76 to $34.43 \%$ wet basis and loading rate of $25 \mathrm{~mm} / \mathrm{min}$., and they found the values of rupture force, toughness, rupture stress, yield force and modulus of stiffness of the seeds to decreased linearly from 362.04 to $168.82 \mathrm{~N}, 1.783$ to $0.623 \mathrm{~J}, 7.4$ to $3.15 \mathrm{~N} / \mathrm{mm}^{2}, 213.42$ to $89.68 \mathrm{~N}$ and 39.6 to $21.97 \mathrm{~N}$ with moisture increase in transverse axis. Whereas for longitudinal loading, the values decreased from 276.64 to $195.26 \mathrm{~N}, 1.355$ to $0.641 \mathrm{~J}, 16.12$ to $6.23 \mathrm{~N} / \mathrm{mm}^{2}, 211.58$ to $124.72 \mathrm{~N}$ and 38.74 to 24.77 $\mathrm{N}$ with an increase in moisture content. The seeds' physical and mechanical properties were affected by moisture content $[3,35]$. However, it was observed that adequate work had not been done on the thermal properties of the seeds despite the fact that heat treatment is essential for its processing.

\section{POSTHARVEST AND STORAGE}

\section{Processing of African oil bean seed}

It has been stated [37] that Ugba contains some anti-nutritional factors like undigestible oligosaccharides and phytate in its natural state, and this make processing inevitable. The processing of the seed into Ugba involves boiling or roasting, dehulling, shredding / slicing, soaking, washing, packaging, and fermenting (Table 5). 
However, the processing method affects the nutrients and phytochemical properties of AOB seeds $U g b a[10,38,39,40,41]$. This revelation makes optimization of the processing method imperative to get the optimal variables for $U g b a$ processing. A study [42] is of the opinion that $U g b a$ should be handled properly during processing in order to take care of the Micrococcus spp and to inhibit the enzyme production responsible for spoilage. Processors can save up to 2 days by using a rapid technique for Ugba processing proposed by [43]. The apparent simple process achieved the same quality of Ugba after fermentation as the much more cumbersome, fuel-wasting and timeconsuming.

\section{Fermentation of African oil bean seed shreds/slices (ugba)}

Some foods are probiotics and must have to undergo fermentation before they are ready to be consumed. Examples of such foods to include wine, yogurt, cheese, alcohol, vinegar and bread [22]. The shreds and slices of cooked African oil bean is fermented before they are consumed.

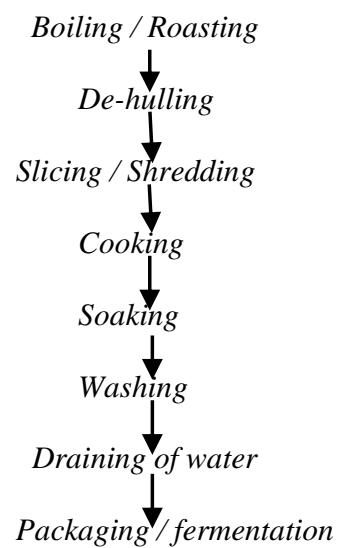

(a)

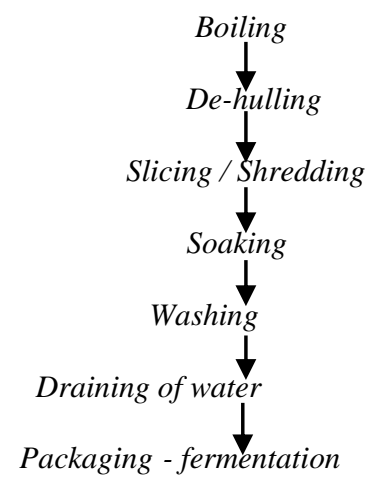

(b)

Fig. 2. Flowchart of Ugba processing

Unfermented shreds/slices are bitter and not tasty. The first stage in the processing is cleaning to remove damaged seeds. After cleaning, the traditional processing operations follows (Figure 2).

However, [44] recommended 2-3 days of fermentation and reported that fermentation for 4 days increased cholesterol levels which could pose a problem for patients of cardiovascular disease-related to cholesterol.

Different processors adopt varying sequence of the processing methods (Table 5), however, there are two main methods of processing African oil bean seeds into Ugba (Figure 2) prevalent within the Southeastern part of Nigeria as reported by local processors. 


\section{Packaging of the shreds/slices of African oil bean seeds}

African oil bean seed shreds and slices are traditionally packaged by wrapping a handful with different kinds of leaves (Figure 1). The wrapping of the seeds with leaves is believed to aid the fermentation process. The leaves wrapping and the poor measures during handling contaminates the product [45]. Also, leaves-wrapping creates openings for microbes to enter the product resulting to rapid deterioration. The leaves-wrapped product has a low shelf life of not more than 5 days under tropical ambient conditions of $31-32^{\circ} \mathrm{C}$.

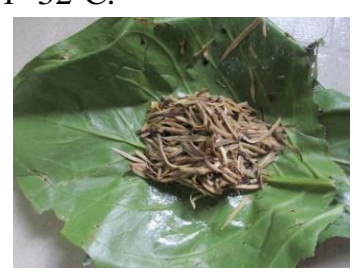

(a)

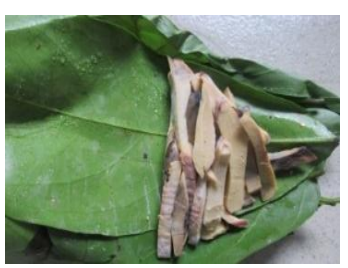

(b)

Fig.1a. AOB shreds

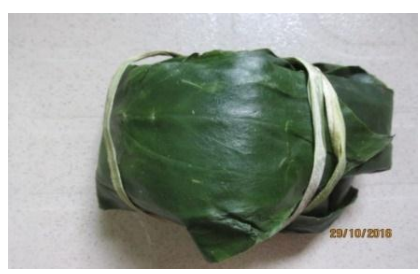

(c)

1c. Wrapped $A O B$ shreds/slices

The type and the number of leaves varies from one processor to another, and they are determined by the processor's discretion and experience. The effect of the type and number of leaves on the quality of wrapping African oil bean shreds was evaluated by [46]. Their study showed that the leaves of plantain (Musa paradisiaca), cocoyam (Xanthosoma sagittifolium) and Okpopia (Alchornea laxifora Benth) did not affect the proximate composition of the product so also the number of leaves used. However, they recommended five leaves of Okpopia (Alchornea laxiflora Benth) for wrapping African oil bean seed slices and shreds because of the high storage quality observed.

Other researchers have studied alternative ways to package and extend the shelf life of African bean seed shreds/slices. The use of canning method of packaging was studied by [47]. They used brine, groundnut and tomato sauce as various media to extend the shelf of African oil bean slices. They observed that canning with media led to softening and colour darkening of the samples over prolonged storage time. Apart from these problems detected, another challenge would be the acceptability of those media with African oil bean slices in dish preparations. This is because the foods prepared with African oil bean does not go with any of those media as an ingredient. In their work, [48] evaluated bottle/cup packaging with locally adapted pasteurization technique as an alternative storage method.

They used starter culture of washed cells of Bacillus subtilis and Bacillus megaterium to ferment the sliced and sterilized slices of African oil bean seeds for 48 hours at room temperature $\left(30 \pm 2{ }^{\circ} \mathrm{C}\right)$. Although they observed no microbial growth on the product at the end of 6 weeks of storage, they did not indicate whether or not the intrinsic properties of the product were affected.

Some other researchers [49] studied the possibility of using polyethene bags and foil wraps with the aid of preservatives to package and extend the storage duration of African oil bean seeds. Their method was able to keep the product for only eight days after which the product quality was found to degrade. 
Besides, some preservatives can alter the organoleptic properties of food, and carrying out tests such as Hedonic, could have been useful in evaluating the effects of the preservatives and storage methods on the organoleptic characteristics of the product.

Notably, the various methods evaluated, when compared to leaves wrapping, have the advantage of reducing or preventing the entrance of microbes that leads to product spoilage. Nonetheless, none of the methods is satisfactory in solving the packaging and storage problems of African oil bean shreds/slices.

Table 5. Processing methods for fermented African oil bean seed

\begin{tabular}{|c|c|c|}
\hline$\overline{S / N}$ & Processing method & Reference \\
\hline$\overline{1}$ & $\begin{array}{l}\text { Boil the seeds for } 4 \text { hours, dehull, slice, boil for another two } \\
\text { hours, drain and soak in water for two hours, wash and } \\
\text { package in leaves for fermentation }\end{array}$ & $[22])$ \\
\hline 2 & $\begin{array}{l}\text { Boil at } 121^{\circ} \text { C for } 1 \text { hour, dehull, wash kernel, drain, rewash } \\
\text { kernel several times in cold water, slice, mix with salt, wrap } \\
\text { with leaves and place in a basket to ferment for } 3-5 \text { days. }\end{array}$ & [50] \\
\hline 3 & $\begin{array}{l}\text { Boil for } 3 \text { hours, dehull, slice, wash and boil for } 2 \text { hours, cool } \\
\text { and soak for } 10 \text { hours, wash, drain water and keep in a basket } \\
\text { lined with banana leaves to ferment }\end{array}$ & [51] \\
\hline 4 & $\begin{array}{l}\text { Boil for } 12 \text { hours, slice, boil for } 24 \text { hours, wash, drain and } \\
\text { allow to ferment }\end{array}$ & [52] \\
\hline 5 & $\begin{array}{l}\text { Boil for } 12 \text { hours, dehull, slice, boil for } 2 \text { hours, wash, wrap } \\
\text { in banana leaves and packaged in the basket for fermentation }\end{array}$ & [16] \\
\hline 6 & $\begin{array}{l}\text { Toast in hot }\left(100^{\circ} \mathrm{C}\right) \text { sand and hold for a further } 30 \mathrm{~min} \text { at } \\
100^{\circ} \mathrm{C} \text {, slice to } 1 \mathrm{~mm} \text {, boil for } 30 \text { mins and soak for } 2 \text { hours. }\end{array}$ & [43] \\
\hline 7 & $\begin{array}{l}\text { Boil for } 12 \text { hours, dehull, slice, boil for } 30 \text { mins, drain, cool, } \\
\text { wash and ferment at room temperature in wraps of heat- } \\
\text { blanched banana leaves }\end{array}$ & [53] \\
\hline
\end{tabular}

\section{Seed storage}

The information obtained from local processors and farmers showed that the seeds of African oil bean are stored in their pods until they are taken to the market or processed.

Farmers do harvest the pods early because of their susceptibility to explode under the intense heat of the sun. The maturity index of the pod is taken as a change in their colour, from green to brown. Some farmers see the maturity index as when any of the pods start to explode. 
Harvested pods are kept in shade or room where sunlight does not touch them. Another way to store the seeds is to remove them from the pods and store in a jute bag or multilayer black polyethene bags. The seeds are removed from matured pods by breaking the pods through their longitudinal axis using a machete or by smashing it on a hard object. Otherwise, the seeds are collected from the farm where they are dispersed after splitting of the pod while still on the tree.

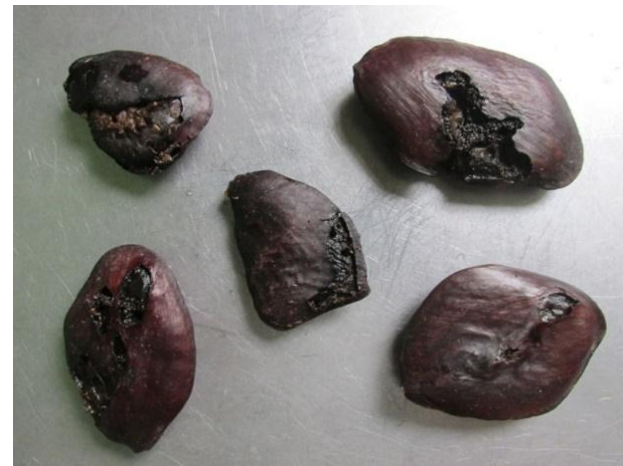

Fig. 3(a). Deteriorated AOB seeds

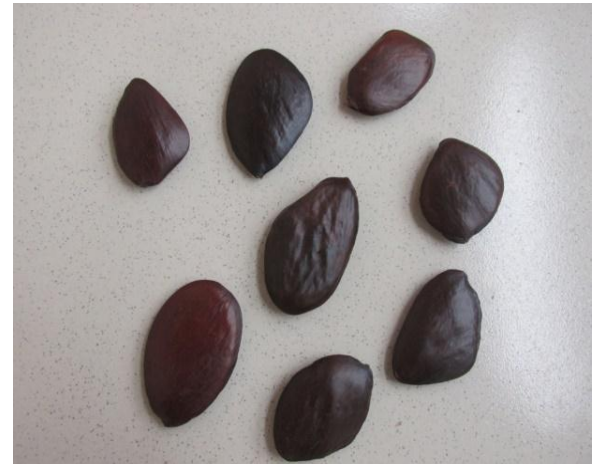

Fig. 3.(b). AOB seeds

The information obtained from local processors showed that the shelf life of the seeds stored in their pods could be up to 6 months, depending on the prevalent ambient conditions, whereas, the jute bag or multilayer black polyethene bag storage shelf life is within three months. However, none of these methods proved to be effective in storing AOB seeds, since some of the products were spoilt over time as shown in Figure 3.

\section{OIL PROSPECTS OF AFRICAN OIL BEAN SEEDS}

The African oil bean seed is rich in oil content (53.98\%) and oleic acid (29.0\%) [54, 55]. The AOB seed oil yield is greater than that of castor bean (42.2\%) and locust bean $(20.68 \%)$ [56]. This high oil content of the seed indicates that processing of the seeds for oil would be economically viable [18]. However, there is no grocery shelve where oil from African oil bean seed is displayed. Such neglect has limited the potential of the crop to date.

The influence of moisture content and seed dimension on the mechanical expression of oil from African oil bean seeds has been evaluated [57]. The research showed an oil yield of $47.7 \%$ and oil expression efficiency of $78.96 \%$ using mechanical oil expression. Also found was that the higher the moisture content and seed dimensions, the lower the quantity of oil expressed by the machine from the seeds.

Mechanical expression of oil seeds does leave some fractions of the oil in the cake, which will require the use of solvent, like food grade n-Hexane, to extract. It implies that solvent extraction will give oil yield higher than $47.7 \%$ obtained by [57]. 


\section{POSTHARVEST CHALLENGES}

\section{Postharvest losses}

Postharvest losses, which refer to losses in quality and quantity, are usually preceded by physical or physiological damage of agricultural produce. Physical damage occurs during harvest, transportation, handling, packaging and in storage for most agricultural products, while physiological damage results from physiological changes that take place after harvest. The African oil bean seeds are hard and are not susceptible to physical damage during postharvest handling. Many post-harvest losses of the seeds are mostly due to physiological damage, pests attack and diseases. The physiological changes are made possible because of high the moisture contents of the seeds at harvest. It was stated by [58] that the two significant factors affecting physiological deterioration of products are pre-harvest factors (temperature, moisture status, mineral nutrition and cultural practices) and postharvest factors (temperature, chilling injury, light, gases such as carbohydrate, oxygen, ethylene). Ugba has a very low shelf life, and whenever the product is not marketed within days of processing, the product will be lost to spoilage.

\section{Dearth of research}

There is a decline in the production of African oil bean seeds because of afforestation, urbanization and lack of planting new trees [59]. Majority of the tree still grows in wild and there is no known plantation for the crop. The seed has only a mono bye-product ( $u g b a$ ) in Nigeria despite its potential for other products. Researchers have focused their attention of the proximate, organoleptic, chemical, nutritional, functional properties, fermentation, phytochemical and health benefits of African oil bean seed [16, $18,31,54,55,60-70]$. The problem of lack of research input from agronomy and engineering disciplines has led to the absence of improved variety and many postharvest challenges, respectively. As a result, the crop could be termed an orphan and endangered species.

\section{RESEARCH NEEDS OF AFRICAN OIL BEAN SEED}

In order to maximize the potential of African oil bean research, there is an urgent need for researchers to look into the following research areas for the crop:

- Development of improved varieties of African oil bean seed

- Optimization of the oil yield of African oil seed

- Characterization of the oil from African oil bean seed

- Evaluation of the drying kinetic of African oil bean shreds/slices for improved shelf life

- Effects of drying on the proximate, phytochemical, mineral and vitamins contents of the African oil bean seed

- Technological development of a proper packaging method for African oil bean seed

- Process optimization of Ugba preparation 


\section{CONCLUSIONS}

The growing population of developing nations has put enormous pressure on the staple food availability of the people, and imported foods are relatively expensive and unaffordable to the majority of the populace due to poverty. To ensure food security in these regions, research on nutritious but neglected crops that grow and flourish with little or no special care, like AOB, should be encouraged. Considering the nutrient attribute, the phytochemical, proximate, mineral and vitamin constituents of African oil bean; the crop could be regarded as a great complementary food for household nourishment and an essential raw material for food and pharmaceutical industries. AOB seed has great prospect of improving the economy of households and the nation through value addition. The exploration of the oil potentials of AOB seed could see the crop compete in world oil-seed trade. Moreover, it brings a high return to investors. Improving the postharvest operations of AOB seed through research could help to tackle food insecurity. Furthermore, there is need to get improved varieties for increased production, and improved research on the postharvest challenges of the crop. So, any value addition on the AOB seed could possibly create wealth and jobs for the teeming youth population of these regions.

\section{REFERENCES}

[1] Orwa C., Mutua, A., Kindt, R., Jamnadass, R., and Simons, A. 2009. Agroforestree Database: a tree reference and selection guide version 4.0. World Agroforestry Centre, Kenya. http://www.worldagroforestry.org/treedb/ (Accessed on October 5th, 2018).

[2] Achinewhu, S.C. 1996. The African Oil Bean (Pentaclethra macrophylla Benth.). In Food and feed from legumes and oilseeds. pp. 130-139. Springer, Boston, MA.

[3] Aremu, A.K., Ademuwagun, A.A., and Ogunlade, C.A. 2014. Effects of moisture content and loading orientation on some mechanical properties of the African oil bean seed (Pentaclethra Macrophylla Benth). African Journal of Agricultural Research, 9(49), 3504-3510. DOI: 10.5897/AJAR2014.9109

[4] Achinewhu, S.C. 1982. Composition and food potential of African oil bean (Pentaclethra macrophylla) and velvet bean (Mucuna uriens). Journal of food scienc, 47, 17361737. https://doi.org/10.1111/j.1365-2621.1982.tb05025.x

[5] Asoegwu, S.N., Ohanyere, S.O., Kanu, O.P., and Iwueke, C.N. 2006. Physical properties of African oil bean seed (Pentaclethra macrophylla). Agricultural Engineering International: the CIGR Ejournal Manuscript, FP 05 006. Vol. VIII.

[6] Ajayi, I.A., and Oderinde, R.A. 2013. A comparative study of the chemical composition of Entada pursaetha and Pentaclethra macrophylla seeds and seed oils. Pak. J. Sci. Ind. Res. Ser. A: Phys. Sci., 56, pp.138-143.

[7] Arueya, G.L., Owoseni, B.S., and Olatoye, K.K. 2017. Development of texturized vegetable protein from lima bean (Phaseolus lunatus) and African oil bean seed [Pentaclethra macrophylla (Benth)]: optimization approach. Acta Universitatis Cibiniensis Series E: Food Technology, 21(1), pp. 61-68.

[8] Liman, A.A., Egwin, P., Vunchi, M.A., and Ayansi, C. 2010. Lipase Activity in Fermented Oil Seeds of Africa Locust Bean, (Parkia Biglobosa), Castor Seeds (Ricinu Communis) and African Oil Bean (Pentaclethra Macrophylla). Nigerian Journal of Basic and Applied Science, 18(1), pp.136-140. 
[9] Anike, I.C. 2019. Effect of fermented Pentaclethra macrophylla Bent (African oil bean) seed extract on plasma lipid profile in healthy rat model-a preliminary study. South Asian Research Journal of Natural Products, 2(1), pp.1-9.

[10] Nwosu, U.C., Essien, E.B., and Ohiri, R.C. 2017. Phytochemical, mineral composition and anti-hyperlipidemic effects of processed Pentaclethra macrophylla seeds on high fat diet and streptozocin-induced diabetic wistar rats. International Journal of Agriculture and Earth Science, 3(6), pp.31-41.

[11] Omeh, Y.N., Garuba, O., Adiele, I.P., and Ejiofor, E.U. 2014. Some kidney function parameters of wistar albino rat fed Pentaclethra macrophylla seeds meal. European Journal of Biotechnology and Bioscience, 2(3), pp.17-20.

[12] Tsobeng, A., Asaah, E., Makueti, J., Tchoundjeu, Z., and Van Damme, P. 2013 Propagation of Pentaclethra macrophylla Benth (Fabaceae) through seed and rooting of leafy stem cuttings. Int. Journal of Agronomy and Agricultural Research, 3(12), 10-20.

[13] Odoemelam, S.A. 2005. Proximate composition and selected physicochemical properties of the seeds of African oil bean (Pentaclethra marcrophylla). Pakistan Journal of Nutrition, 4(6), pp.382-383.

[14] Ajayi, I.A. 2010. Physicochemical attributes of oils from seeds of different plants in Nigeria. Bull. Chem. Soc. Ethiop, 24, pp. 145-149.

[15] Okoye, E.I. 2016. Extraction, characterization and pharmaceutical screening of oil obtained from seeds of Pentaclethra macrophylla Benth (African oil bean seed). The Pharmaceutical and Chemical Journal, 3(2), pp. 88-91.

[16] Okwu, D.E., and Aluwuo, C.J. 2008. Studies on the phytochemical composition and fermentation of the seeds of African oil bean tree (Pentaclethra macrophylla Benth). Int. J. Chem. Sci, 6(2), pp.773-788.

[17] Achinewhu, S.C., and Ryley, J. 1986. Effect of fermentation on the thiamin, riboflavin and niacin contents of melon seed (Citrullus vulgaris) and African oil bean seed (Pentaclethra macrophylla). Food chemistry, 20, pp. 243-252.

[18] Ikhuoria, E.U., Aiwonegbe, A.E., Okoli, P., and Idu, M. 2008. Characteristics and composition of African oil bean seed (Pentaclethra macrophylla Benth). Journal of Applied Sciences, 8(7), pp.1337-1339.

[19] Enujiugha, V.N., Badejo, A.A., Iyiola, S.O., and Oluwamukomi, M.O. 2003. Effect of germination on the nutritional and functional properties of African oil bean (Pentaclethra macrophylla Benth) seed flour. Food, Agriculture \& Environment, 1(3\&4), pp.72-75.

[20] Nwachukwu, C.D., Enyoh, E.C., Enyoh, C.E., and Amaobi, C.E. 2018. Effect of fermentation time on the proximate and mineral composition of fermented African oil bean seed 'ugba'. Sustainable Food Production, 2, pp.13-20.

[21] Ogbuagu, M.N., Ubani, L.O., Ezenobi, V.U., and Mgbachi, I. 2018. Effect of extent of fermentation on the amino acid composition of African oil bean (Pentaclethra macrophylla, Benth). Seed. J. Chem Soc. Nigeria, 43(3), pp.613-620.

[22] Mbah, G.O., Onyeabo, U.A., and Udeh, B.C. 2018. Effect of fermentation on nutritional composition of African oil bean seed. The Pacific Journal of Science and Technology, 19(1), pp. 244-250.

[23] Opara, C.C., Inyang, I., and Iheonye, K.A. 2013. Kinetics of fermentation of oil bean seed. Annals. Food Science and Technology, 14(1), pp. 68-72.

[24] Ogbulie, T.E., Nsofor, C.A., and Nze, F.C. 2014. Bacteria species associated with ugba (Pentaclethra macrophylla) produced traditionally and in the laboratory and the effect of fermentation on product of oligosaccharide hydrolysis. Nig. Food J., 32(2), pp.73-80.

[25] Abiodun, I.S., Onilude, A., Fadahunsi, I., Ogunbanwo, S., and Afolabi, R. 2002. Selection of starter cultures for the production of ugba, a fermented soup condiment. Eur Food Res Technol, 215, pp. 176-180. 
[26] Azi, F., Njoku, H.A., David, E.I., Odo, M.O., Nwobasi, V.N., Tu, C., and Dong, M. 2019. Effect of processing aid on the chemical composition and metagenomics of fermented African oil bean seed (Pentaclethra macrophylla, Benth). LWT, 111, pp.429-435. https://doi.org/10.1016/j.lwt.2019.05.056

[27] Okafor, J.C., Okolonkwo, U.C., and Ejiofor, M.A.N. 1991. Evaluation of oils from fermented and unfermented seeds of the African oil bean tree Pentaclethra macrophylla. International Tree Crops Journal, 7(1-2), pp.95-101.

[28] Adekoya, I., Obadina, A., Phoku, J., Nwinyi, O., and Njobeh, P. (2017). Contamination of fermented foods in Nigeria with fungi. $L W T, 86$, pp.76-84.

[29] Nwuche, C.O. 2013. Isolation of bacteriocin - producing lactic acid bacteria from 'ugba' and 'okpiye', two locally fermented Nigerian food condiments. Braz. Arch. Biol. Technol, 56(1), pp.101-106.

[30] AOCC 2019. African orphan crops consortium: healthy Africa through nutritious, diverse and local food crops. http://africanorphancrops.org/meet-the-crops/. (Accessed on October 21, 2019).

[31] Aladekoyi, G., Orungbemi, O.O., Karimu, O.A., and Aladejimokun, A.O. 2017. Comparative studies of the nutritional and phytochemical constituents of African oil bean (Pentaclethra macrophylla Benth) and African bean (Anthonotha macrophylla) for human consumption. Chemistry Research Journal, 2(3), pp.16-21.

[32] Oboh, G. 2019. Pentaclethra macrophylla Benth. PROTA [Plant Resources of TropicalAfrica/Ressources végétales de l'Afrique tropicale)], Wageningen, Netherlands. Retrieved from http://www.prota4u.org/search.asp. (Accessed on October 8, 2019)

[33] Igbozulike, A. O., and Aremu, A. K. 2009. Moisture dependent physical properties of Garcinia kola seeds. Journal of Agricultural Technology, 5(2), pp. 239-248.

[34] Bajpai, A., Kumar, Y., Singh, H., Prabhakar, P. K., and Meghwal, M. 2019. Effect of moisture content on the engineering properties of Jamun (Syzgium cuminii) seed. Journal of Food Process Engineering, e13325. DOI: 10.1111/jfpe.13325

[35] Oduma, O., Onu, O.O., and Igwe, J.E. 2016. Moisture content on some physical and mechanical properties of an African oil bean seeds (Pentaclethra macrophylla). Umudike Journal of Engineering and Technology, 2(2), pp.78-85.

[36] Ndukwu, M.C. S. I. Manuwa, O. J. Olukunle, I. B. Oluwalana. 2013. Development of an active evaporative cooling system for short-term storage of fruits and vegetable in a tropical climate. Agricultural Engineering Int. CIGR Journal. Vol.15.Iss.4. pp.307-313

[37] Nurudeen A. Olasupo, Chimezie P.Okorie, and Falarian A. Oguntoyinbo. 2016. The Biotechnology of Ugba, a Nigerian Traditional Fermented Food Condiment. Frontiers Microbiology, Vol.7. Article 1153. pp.1-10. doi:10.3389/fmicb.2016.01153

[38] Ojiako, O.A., Ogbuji, C.A., Agha, N.C., and Onwuliri, V.A. 2010. The proximate, mineral, and toxicant compositions of four possible food security crops from Southeastern Nigeria. Journal of Medicinal Food, 13(5), pp.1203-1209.

[39] Okorie, P.C., and Olasupo, N.A. 2014. Effect of processing method and fermentation on the antinutritional factors/phytochemical contents of African oil bean seed. International Journal of Scientific \& Engineering Research, 5(5).

[40] Archibong, E.J., Alor, C.J., and Okoro, N.C. 2017. Comparative Studies of Ugba Qualities Using Six (6) Processing Methods. Nigerian Journal of Microbiology, 31, pp.4014-4021.

[41] Oly-Alawuba, N., and Anunukem, D. 2018. Effect of processing methods on the nutrient and phytochemical properties of African oil bean seeds (Pentaclethra macrophylla), "Ugba". Journal of Food Science and Engineering, 8, pp. 191-197. doi: 10.17265/2159. 5828/2018.05.001

[42] Oyedeji, F.N., and Ijigbade, B. 2016. Growth and extracellular enzyme production of micrococcus species from fermented "Ugba". NYSci J.9(2), pp. 93-97.

doi:10.7537/marsnys09021616. 
[43] Sokari, T.G., and Wachukwu, C.K. 1997. Simple rapid processing of African oil bean seeds for ugba production. Int. Journal of Food Science and Technology, 32, 77-79.

[44] Monago, C.C., Ogbomeh, P.A., and Joshua, P.E. 2004. Effect of African oil bean seed (Pentaclethra macrophylla) on blood cholesterol levels in rats. Global Journal of Pure and Applied Sciences, 10(1), pp. 165-168.

[45] Nwagu, T.N., Amadi, C., and Alaekwe, O. 2010. Role of Bacteria isolates in the spoilage of fermented African oil bean seed ugba. Pakistan J. of Biolog.Sciences, 13(10), 497-503.

[46] Kabuo, N.O., Asoegwu, S.N., Nwosu, J.N., Onuegbu, N.C., Akajiaku, L.O., and Nwaimo, J.C. 2015. Assessment of leaf-type and number of leaves used in wrapping on the quality of "Ugba" (fermented Pentaclethra macrophylla Benth). European Journal of Food Science and Technology, 3(1), pp.11-23.

[47] Enujiugha, V.N., and Akanbi, C.T. 2008. Quality evaluation of canned fermented oil bean seed slices during ambient storage. African Journal of Food Science, 2(5), pp.54-59.

[48] Mbata, T., and Orji, M.U. 2007. Process optimization in the production and preservation of ugba, a Nigerian fermented food. International Journal of Microbiology, 4(2), 1-5.

[49] Ogbulie, J.N., Njoku, H.O., Uwaezuoke, J.C., and Onyicha, R.I. 1998. Evaluation of packaging materials for the preservation of African oil bean (Pentaclethra macrophylla) for the production of ugba. J Innov Life Sci, 3, pp.110-118.

[50] Eze, V.C., Onwuakor, C.E., and Ukeka, E. 2014. Proximate composition, biochemical and microbiological changes associated with fermenting African oil bean (Pentaclethra macrophylla Benth) seeds. American Journal of Microbiological Research, 2(5), 138-142.

[51] Okereke, A.N., and Onunkwo, D.N. 2014. Effect of Processing Methods on Proximate Composition and Sensory Properties of "Ugba" (Pentaclthra Macrophylla Benth) an African Oil Bean Product. IOSR Journal of Environmental Science, Toxicology and Food Technology, 8(11), pp. 32-38.

[52] Balogun, B.I. 2013. Evaluation of the nutritional potentials of fermented oil beans seed (Pentaclethra macrophylla, Benth). Production Agr. and Technology (PAT), 9(2), 73-87.

[53] Isichei, M.O., and Achinewhu, S.C. 1988. The nutritive value of African oil bean seeds (Pentaclethra macrophylla). Food Chemistry, 30, pp.83-92.

[54] Enujiugha, V.N., and Akanbi, C.T. 2005. Compositional changes in African oil bean (Pentaclethra macrophylla Benth) seeds during thermal processing. Pakistan Journal of Nutrition, 4(1), pp. 27-31.

[55] Ogueke, C.C., Nwosu, J.N., Owuamalam, C.I., and Iwouno, J.N. 2010. Ugba, the fermented African oil bean seeds; its production, chemical composition, preservation, safety and health benefits. Pakistan Journal of Biological Sciences, 13(10), pp.489-496.

[56] Talabi, J.Y., and Enujiugha, V.N. 2014. Physical and chemical evaluation of oils from selected underutilized oilseeds. Pelagia Research Library, 5(6), pp.9-12.

[57] Aremu, A. K., and Ogunlade, C. A. 2016. Effect of operating parameters on mechanical oil expression from African oil bean seeds. Global Journal of Science Frontier Research: D, Agriculture and Veterinary, 16(1), pp.19-26.

[58] Guru, S.K., and Mishra, S. 2017. Physiological factors leading to post-harvest crop losses. Training proceeding on Technological Advances to Minimize Pre-and Post-Harvest Losses in Agricultural and Horticultural Crops to Enhance Farmer's Income. pp. 68-76.

[59] Osondu, C.K., Obike, K.C., and Nwadike, F.C. 2015. Determinants of net returns of African oil bean seed (Pentaclethra Macrophylla: Benth) marketing in south eastern Nigeria. Nigerian Journal of Agriculture, Food and Environment, 11(4), pp.103-111.

[60] Obeta, J.A.N. 1983. A note on the micro-organisms associated with the fermentation of seeds of the African oil bean tree (Pentaclethra macrophylla). Journal of Applied Bacteriology, 54(3), pp.433-435.

[61] Kingsley, M.O. 1995. Effect of processing on some antinutritive and toxic components and on the nutritional composition of the African oil bean seed (Pentaclethra macrophylla Benth). Journal of the Science of Food and Agriculture, 68(2), pp.153-158. 
[62] Isu, N.R., and Njoku, H.O. 1997. An evaluation of the microflora associated with fermented African oil bean (Pentaclethra macrophylla Bentham) seeds during ugba production. Plant foods for human nutrition, 51(2). pp.145-157.

[63] Akindahunsi, A.A. 2004. Physicochemical studies on African oil bean (Pentaclethra macrophylla Benth.) seed. Journal of Food, Agriculture \& Environment, 2, pp.14-17.

[64] Alinnor, I.J., and Oze, I.R. 2011. Chemical evaluation of the nutritive value of Pentaclethra macrophylla Benth (African oil bean) seeds. Pakistan Journal of Nutrition, 10(4), pp.355-359.

[65] Kabuo, N.O., Uzuegbu, J.O., Ubaonu, C.N., and Onyeka, E.U, 2013. The microorganisms and compounds influencing the organoleptic properties of ugba (fermented Pentaclethra macrophylla Benth. seeds). African J. of Food Science, 7(2), 25-34. DOI: 10.5897/AJFS11.195

[66] Okorie, C.P., and Olasupo N.A. 2013. Controlled fermentation and preservation of UGBA -an indigenous Nigerian fermented food. SpringerPlus, 2:470. pp. 1-9

[67] Balogun, B.I., Okeh, D.B.I., and Ekwemgbo, P.A. 2014. Evaluation of the nutritional potentials of fermented oil bean seed Pentaclethra macrophyllah Benth. Agricultural Advances, 3(7), 202-209. doi:10.14196/aa.v3i7.1621

[68] Olotu, I.O., Enujiugha, V.N., and Obadina, A.O. 2014. The effect of $\gamma$-irradiation and cooking on the amino acid profile of African oil bean seed (Pentaclethra macrophylla benth). J. of Food Processing and Preservation, 38, 2020-2026. doi:10.1111/jfpp.12179

[69] Onabanji, A.O. 2015. Physiochemical properties of two commonly eaten Nigeria salads (Pentaclethra Macrophylla Benth and Gnethun Africanum). Journal of Natural Sciences Research, 5(14), pp. 72-75.

[70] Osabor, V.N., Okonkwo, P.C., and Ikeuba, A.I. 2017. Chemical profile of leaves and seeds of Pentaclethra macrophylla Benth. J. Med. Plant Herb. Ther. Res, 5, pp.11-17.

\section{OBRADA POSLE ŽETVE, PAKOVANJE I SKLADIŠTENJE AFRIČKOG SEMENA (ZRNA) ZA ULJE}

\section{Augustine Onyekachi Igbozulike ${ }^{1}$, Victor Ifeanyichukwu Obiora Ndirika ${ }^{1}$, Kayode Joshua Simonyan ${ }^{1}$}

${ }^{I}$ Agricultural and Bioresources Engineering Department, College of Engineering and Engineering Technology, Michael Okpara University of Agriculture, Umudike 
Sažetak: Nedovoljna upotreba Afričkog zrna (semena) (Pentaclethra macrophilla Benth.) za ulje, zahteva proučavanje operacija posležetvenih postupaka. Ovaj rad daje pregled stanja i situacije istraživanja procesa žetve Afričkog semena (zrna) za ulje (AUS). Informacije su dobijene putem upita za pretragu, obradu, pakovanje i skladištenje afričkog zrna (semena) posle berbe, kao ključne reči na Google Scholar info sistemu, internetu, veb lokaciji izdavača, udžbenicima i usmenim intervjuima sa lokalnim proizvođačima ove kulture. Rezultati su pokazali da su straživači fokusirani na fermentacioni, fitohemijski, mineralni i vitaminski sastav afričkog zrna -semena za ulje (AUS). Ova studija je takođe otkrila nedostatak istraživanja o karakterizaciji, poboljšanoj sorti, pakovanju, skladištenju, dodavanju vrednosti i ekstrakciji ulja iz zrna (semena).

Istraživanje rukovanja, skladištenja, pakovanja i prerade AUS semena (zrna) nakon berbe neophodno je za optimalno korišćenje semena i za sprečavanje raširenih gubitaka posle berbe.

Ključne reči: Afričko seme (zrno) za ulje, pakovanje, prerada, skladištenje, dodate vrednosti.

Prijavljen:

Submitted: 07.10.2020.

Ispravljen:

Revised: $\quad 10.12 .2020$.

Prihvaćen:

Accepted: 20.01.2021. 